p-ISSN 0030-9311; e-ISSN 2338-476X; Vol.56 No.5(2016) p.298-304; doi: 10.14238/pi56.5.2016.298-304.

Original Article

\title{
Associations of maternal body composition and nutritional intake with fat content of Indonesian mothers' breast milk
}

\author{
Ardesy Melizah Kurniati ${ }^{1}$, Diana Sunardi ${ }^{2}$, Ali Sungkar ${ }^{3}$, Saptawati Bardosono ${ }^{2}$, \\ Neng Tine Kartinah ${ }^{4}$
}

\begin{abstract}
Background Breast milk fat content accounts for the largest part of infants' energy and may be influenced by many factors, including maternal factors, which may vary in different settings. So far, there has been no published data no published data on whether the breast milk fat content of Indonesian mothers is affected by their body composition or nutritional intake.

Objective To investigate breast milk fat content of Indonesian mothers and its associations with maternal body composition and nutritional intake.

Method This cross-sectional study was conducted at Budi Kemuliaan Mothers' and Children's Hospital. Breast milk specimens were collected from 48 nursing mothers, centrifuged, and tested by creamatocrit for fat content. A 24-hour food recall was performed to evaluate maternal macronutrient intake. Maternal body composition was evaluated by bioelectric impedance analysis. Univariable correlations between breast milk fat content and either energy and macronutrient intake were assessed using the Spearman rho test.

Results All nursing mothers had breast milk fat content within clinically normal range [mean 59.4 (SD 15.9) g/L]. There was no significant correlation between milk fat content and maternal body fat $(\mathrm{r}=-0.03, \mathrm{P}=0.840)$, total body water $(\mathrm{r}=0.09 \mathrm{P}=0.509)$, or muscle mass $(\mathrm{r}=0.08, \mathrm{P}=0.577)$. Milk fat content seemed to weakly correlated with maternal fat intake, although it was not statistically significant $(\mathrm{r}=0.27, \mathrm{P}=0.065)$.

Conclusion Breast milk fat content at one-month post delivery appears appear not to be associated with with maternal body composition. It seems to weakly correlate with maternal fat intake. [Paediatr Indones. 2016;56:298-304. doi: 10.14238/ pi56.5.2016.298-304].
\end{abstract}

Keywords: breast milk; milk fat; energy intake; maternal body composition
$\mathrm{B}$ reast milk is the ideal nutritional source for infants' growth and development. The nutrient content of breast milk is easier for infants' digestive systems to digest and absorb. ${ }^{1,2}$ Breast milk provides sufficient energy for infants during the first six months after birth. ${ }^{3}$ Despite this information, in Indonesia, the prevalence of exclusive breastfeeding in the first six months of infant life has fluctuated, at 40\% in 2002, declining to $32 \%$ in 2007, and climbing back up to $42 \%$ in 2012. Moreover, the percentage of exclusive breastfeeding decreased with increasing infant age, from $39.8 \%$ in infants in the first month of life to $15.3 \%$ at 5 months of age. ${ }^{4}$ Breast milk fat content contributes to most of infants' energy (up to 50\%). ${ }^{1}$ Fat globules are formed in the breast alveoli, ${ }^{5}$ with most substrates obtained from circulation in the form of chylomicron and very low density lipoprotein (VLDL). ${ }^{6}$ Other sources are derived from de novo synthesis in the breast, which

From Department of Nutritional Science, Sriwijaya University Medical School, Palembang, South Sumatera ${ }^{1}$, and Department of Nutrition ${ }^{2}$, Department of Obstetrics and Gynecology ${ }^{3}$, Department of Physiology ${ }^{4}$, University of Indonesia Medical School/Dr. Cipto Mangunkusumo Hospital, Jakarta, Indonesia.

Reprint requests to: Ardesy Melizah Kurniati, Department of Nutritional Science, Sriwijaya University Medical School, Jalan Dr. Moh Ali Komplek RSMH, Palembang 30126, Indonesia. Telp. +62-711-373438; Fax. +62711-373438; Email: ardesy.gizi@fk.unsri.ac.id. 
mainly produces medium-chain fatty acids, and lipolysis in adipocytes, which mainly produces longchain fatty acids. ${ }^{1,6}$ Fatty acids in milk are mainly derived from intake, and detectable 6 hours after food containing certain fatty acids is consumed. ${ }^{?}$

The fat content of breast milk varies among nursing mothers. Fats that are secreted into the milk may undergo changes over time. ${ }^{1,5,8}$ Maternal factors such as maternal age,${ }^{9}$ parity, ${ }^{10-13}$ and gestational age at the time of delivery, ${ }^{10}$ may influence the fat content of breast milk. The fat from body storage, as well as dietary fat and carbohydrates are substrates for milk fatty acids, ${ }^{14}$ while water is the largest component of breast milk (87-90\%). ${ }^{15}$ High calorie diets with zero fat increase de novo synthesis. Low calorie diets with zero fat increase lipolysis in adipocytes. ${ }^{16}$ Maternal intake and body composition are factors that can be changed to achieve adequate fat content in milk. Wan et al. ${ }^{17}$ found that high fat content in milk was likely due to changing dietary patterns, but no correlation was found in the study by Antonakou et al. ${ }^{13}$ Groups of mothers that had consumed high-fat and low-fat diets showed no significant differences in total fat content in a study by Nasser et al., ${ }^{18}$ however, Mohammad et al. found differences. ${ }^{19}$ Studies on maternal body fat mass have also been inconclusive. Body fat mass was positively correlated with fat content in breast milk in studies by Villalpando et al. ${ }^{20}$ and Barbosa et al., ${ }^{21}$ but Quinn et al. ${ }^{22}$ reported that body fat mass was not a predictor of breast milk fat content. The aim of the study was to investigate breast milk fat content of Indonesian mothers at 1 month after delivery and to assess for possible correlations between breast milk fat content and either maternal body composition or nutritional intake.

\section{Methods}

We recruited 48 nursing mothers aged 20-35 years old, one month after delivering a single term infant, had parity of three or less, had no breast infection, and exclusively breastfed. Subjects were recruited consecutively from Budi Kemuliaan Mothers' and Children's Hospital from September 2014 to January 2015. All mothers provided written informed consent. The study was approved by Medical Ethics Commitee of the University of Indonesia.
We interviewed mothers to collect demographic data, including age, parity, and educational level. Subjects did a 24-hour food recall and we used a food model to calculate their energy and macronutrient dietary intake using the Nutrisurvey software. Findings were then compared to the recommended daily allowances (RDA) and defined as adequate if energy intake was $70-100 \% \mathrm{RDA}$ or macronutrient intake was $80-100 \%$ RDA). ${ }^{28}$ Maternal height was measured with a stadiometer. Body composition was assessed by a body composition analyzer (Tanita BC-571), while mothers wore light clothing without socks, watches, or other jewelry.

A mid-feed sample of breast milk ${ }^{23}$ were collected in the morning between 06.00 and 08.00 AM. ${ }^{24}$ Each sample $(15 \mathrm{~mL})$ was collected using an electric double pump (Medela Freestyle ${ }^{\mathrm{TM}}$ ) and fat content of milk was determined with a creamatocrit (Medela Creamatocrit Plus ${ }^{\mathrm{TM}}$ ), as previously described. The breast mik fat content data has been published in Jurnal Perinasia. ${ }^{25}$ Breast milk fat content was considered normal if it was between 30 and 50 $\mathrm{mg} / \mathrm{dL} .{ }^{1}$ All statistical calculations were performed with SPSS statistical software (version 11.5). Normality test was performed using Kolmogorov-Smirnov test. Results with normal distribution are presented as mean and standard deviation (SD); results with abnormal distribution are presented as median (minimum-maximum). Rank Spearman's correlation test was performed to analyze for correlations between breast milk fat content and either nutritional intake or maternal fatness and findings were expressed as 'rho' ( $\mathrm{r}$ or correlation coefficient), in which an $\mathrm{r}$ values of $<0.4$ corresponded to a weak correlation, 0.4 to 0.6 to moderate, and $>0.6$ as a strong correlation. Statistically significant differences were determined at $P$ value of less than $0.05 .^{26}$

\section{Results}

Subjects' characteristics are summarized in Table 1. There were 31 subjects aged 20-29 years and 17 subjects aged 30-35 years. Most subjects were multiparous, had moderate level of education, and nutritional status of overweight/obese.

Maternal body composition data are presented 
Ardesy M. Kurniati et al: Associations of maternal body composition and nutritional intake with breastmilk fat content

in Table 2. Mean body fat mass percentage was 36.1 (SD 7.1) \%, which was above the normal range of 25.1-34.9\%. ${ }^{27}$ Most subjects had high body fat mass $(56 \%)$. All subjects had low total body water $(<55 \%)$, and normal muscle mass percentage $(\geq 42 \%)$.

Table 1. Maternal demographic, anthropometric, and nutritional status characteristics

\begin{tabular}{lc}
\hline Maternal characteristics & $\mathrm{N}=48$ \\
\hline Mean age (SD), years & $27.3(4.4)$ \\
Median parity (range & $2(1-3)$ \\
Parity status, $\mathrm{n}(\%)$ & \\
1 & $17(35)$ \\
2 & $23(48)$ \\
3 & $8(17)$ \\
Educational level, $\mathrm{n}(\%)$ & \\
$\quad$ Low & $5(10)$ \\
Moderate & $34(71)$ \\
High & $9(19)$ \\
Mean height (SD), cm & $153.3(5.3)$ \\
Mean weight (SD), kg & $61.9(14.1)$ \\
Median BMl (range), kg/m² & $25.9(18.1-41.8)$ \\
Nutritional status, $\mathrm{n}(\%)$ & \\
Underweight & $2(4)$ \\
Normoweight & $18(38)$ \\
Overweight & $11(23)$ \\
Obese & $17(35)$ \\
\hline
\end{tabular}

Maternal energy and macronutrient intake are presented in Table 3. Mothers' mean energy and macronutrient intake were adequate. One subject restricted her water intake $(0.9 \mathrm{~L})$, though no subjects avoided certain kinds of food.

Table 2. Maternal body composition characteristics

\begin{tabular}{lc}
\hline Body composition & $\mathrm{N}=48$ \\
\hline Mean body fat (SD), \% & $36.1(7.1)$ \\
Level of body fat mass, $\mathrm{n}(\%)$ & \\
$\quad$ Low & $3(6)$ \\
$\quad$ Normal & $18(38)$ \\
High & $27(56)$ \\
Mean total body water (SD), \% & $46.4(3.6)$ \\
Mean muscle mass (SD), kg & $36.5(3.9)$ \\
\hline
\end{tabular}

Most subjects (73\%) had milk fat content above $50 \mathrm{~g} / \mathrm{L}$, while the remaining (27\%) were within normal range of 30-50 g/L. No subjects had milk fat content under $30 \mathrm{~g} / \mathrm{L}$. No statistically significant correlations between breast milk fat content and either maternal body fat mass, total body water, or muscle mass (Table 4). Likewise, no statistically significant correlations between the fat content of breast milk and intake of energy, fat, carbohydrates, protein, or water (Table 5) although milk fat content seemed to weakly correlated with maternal fat intake.
Table 3. Maternal energy and macronutrient intake, as estimated from 24 hour food recall

\begin{tabular}{lc}
\hline Energy and macronutrients & $\mathrm{N}=48$ \\
\hline Median energy (range), kcal & $2,740.3(1,552.7-6,208.6)$ \\
Energy intake status, $\mathrm{n}(\%)$ & $1(2)$ \\
$\quad$ Below required & $18(38)$ \\
$\quad$ Adequate & $29(60)$ \\
$\quad$ Above required & $84.3(23.2-382.5)$ \\
Median fat (range), g & \\
Fat intake status, $\mathrm{n}(\%)$ & $12(25)$ \\
$\quad$ Below required & $9(19)$ \\
Adequate & $27(56)$ \\
Above required & $375.5(169.5-763.5)$ \\
Median carbohydrate (range), g & \\
Carbohydrate intake status, & $7(15)$ \\
$\mathrm{n}$ (\%) & $14(29)$ \\
$\quad$ Below required & $27(56)$ \\
Adequate & \\
Above required & $98.6(35.8)$ \\
Mean protein (SD), g & \\
Protein intake status, $\mathrm{n}(\%)$ & $6(12)$ \\
$\quad$ Below required & $8(17)$ \\
Adequate & $34(71)$ \\
Above required & $3.42(0.9-12.4)$ \\
Median water (SD), $\mathrm{L}$ & \\
Water intake status, $\mathrm{n}(\%)$ & $3(6)$ \\
Below required & $12(25)$ \\
Adequate & $33(69)$ \\
Above required & \\
\hline &
\end{tabular}

Table 4. Analysis of maternal body composition and breast milk fat content

\begin{tabular}{lcc}
\hline \multirow{2}{*}{ Body composition } & \multicolumn{2}{c}{ Breast milk fat content } \\
\cline { 2 - 3 } & \multicolumn{1}{c}{ r value } & $\mathrm{P}$ value \\
\hline Baby fat mass & -0.03 & 0.840 \\
Total body water & 0.09 & 0.509 \\
Muscle mass & -0.08 & 0.577 \\
\hline
\end{tabular}

Table 5. Analysis of breast milk fat content and maternal energy macronutrient intake

\begin{tabular}{lcc}
\hline & \multicolumn{2}{l}{ Breast milk fat content } \\
\cline { 2 - 3 } Energy and macronutrient & r value & $\mathrm{P}$ value \\
\hline Energy & 0.16 & 0.290 \\
Fat & 0.27 & 0.065 \\
Carbohydrate & 0.03 & 0.838 \\
Protein & 0.19 & 0.197 \\
Water & -0.11 & 0.443 \\
\hline
\end{tabular}

\section{Discussion}

Our study found that approximately two-thirds of mothers had high breast milk fat content ( $>50 \mathrm{mg} / \mathrm{dL}$ ). Breast milk fat content appeared to weakly correlated 
with maternal fat intake although not statisticall significant. No correlation was found between breast milk fat content and maternal fatness.

All of our subjects were in their reproductive age range (20-35 years), the age when they occur on the breast tissue development. ${ }^{29,30}$ A previous study found that this age group was most successful at breastfeeding in the first two months after birth, although its influence was not significant. ${ }^{31}$ Another study reported that maternal age and parity affected patterns of breastfeeding. Multiparous mothers over the age of 20 years had more success at exclusive breastfeeding than primiparous mothers aged less than 20 years. Presumably, this pattern is due to past maternal experience and confidence in caring for infants and breastfeeding. ${ }^{32}$

Amin et al. reported a positive effect between maternal educational level and exclusive breastfeeding success in the first 2 months. ${ }^{31}$ Similarly, Kristiansen et al. ${ }^{33}$ and Al-Sahab et al. ${ }^{34}$ found a strong relationship between the maternal educational level and duration of exclusive breastfeeding. Higher maternal educational level allows mothers to more easily receive and understand information about exclusive breastfeeding, thus affecting the mothers' decisions on the best food for their infants.

The weight of lactating mothers is affected by weight gain during pregnancy, which is determined by the ideal weight before pregnancy. Most subjects in our study were overweight or obese. This research was conducted at one-month postpartum, therefore, overweight might have occurred during pregnancy or before pregnancy. ${ }^{35}$ Mothers' mean BMI was 26.3 (SD $5.4) \mathrm{kg} / \mathrm{m}^{2}$, similar to a study by Choua et al. who found that mothers' mean BMI was 26.2 (SD 4.5) $\mathrm{kg} / \mathrm{m}^{2}$ at one-month postpartum. This BMI did not change significantly throughout the six-month period. ${ }^{36}$

Fat mass deposited during pregnancy becomes the fat source used for lactation. ${ }^{37}$ Mothers' mean body fat mass was 36.1 (SD 7.1)\%, and most subjects had excess body fat mass. There are cut-off for body fat mass based on BMI according to Gallagher et al. ${ }^{27}$ that used in this study. Body fat reserves account for the $150 \mathrm{kcal}$ energy requirement for milk production, 37 and are the source of most long-chain fatty acids contained in breast milk. 6 With enough body fat reserves, mothers are expected to produce adequate milk fat content.
Total body fluid levels fluctuate throughout the day. The body tends to be dehydrated after a long night's sleep. ${ }^{38}$ All subjects had a total body fluid below $55 \%$. Since examination of subjects' body composition was done in the morning, a limited time span after a night's sleep, breastfeeding in the morning, and going to the hospital where this study was held, may not have been long enough to restore normal hydration status. Nursing mothers should consume adequate water, as breast milk is mostly water. ${ }^{15}$ If nursing mothers do not have adequate water intake, water loss through urination and evaporation (insensible water loss) will decrease before the water supply for milk production is disrupted. ${ }^{10}$ Furthermore, insufficient water intake can lead to dehydration and disrupted maternal metabolism, including metabolism to produce breast milk fat.

All subjects had normal muscle mass percentage, indicating that the ratio of muscle mass to body weight tends to be stable, regardless of the weight of the subjects. Normal muscle mass in women reaches $42 \%$ of body weight, with $10 \%$ in smooth and cardiac muscle. The muscles require adenosine triphosphate (ATP) as the only source of energy that can be directly used for contraction. Muscle tissue provides only limited amounts of ATP, so the body must continue to provide it from another source. ${ }^{39}$ Nursing mothers who have high physical activity will require more energy for muscle metabolism, thus reducing body fat mass. Therefore, they should consume more energy, because the milk production, including the fat component, also requires energy. In our study, subjects were generally considered to have inactive lifestyles (little or no exercise), considering that they were only one-month postpartum.

Energy intake by nursing mothers is used to meet the needs for maternal energy and breast milk production. Energy RDAs of Indonesia are categorized by age range. Mothers 19-29 years of age within the first six months of breastfeeding require food intake with energy content of 2,580 kcal, $75 \mathrm{~g}$ fat, $354 \mathrm{~g}$ carbohydrates, and $56 \mathrm{~g}$ protein daily. Breastfeeding mothers aged $30-49$ years need 2,480 kcal of energy, $71 \mathrm{~g}$ fat, $368 \mathrm{~g}$ carbohydrate, and $57 \mathrm{~g}$ protein daily for the first six months of nursing. ${ }^{28}$

The food intake of the majority of subjects exceeded the minimum requirement of energy and macronutrients. Nevertheless, there was still a small

Paediatr Indones, Vol. 56, No. 5, September 2016 • 301 
fraction of subjects with food intake of less than the minimum requirements of energy, carbohydrates, and protein. In addition, a quarter of the number of subjects consumed less fat. With the maternal need to produce milk, it is often assumed that a mother should eat in large quantities, thus breastfeeding mothers are usually encouraged to overeat. Conversely, mothers who want to return to their normal weight before pregnancy tend to consume less than the required amounts, either by implementing their pre-pregnancy diet or simply reducing portions and types of food eaten.

Our subjects had an average of 30\% fat, $56 \%$ carbohydrate, and $14 \%$ protein of energy intake. Of the three macronutrients, only fat intake was above the recommended guidelines for balanced nutrition ( $<25 \%$ of energy intake), and carbohydrate intake was slightly above the minimum percentage $(55 \%$ of energy intake). This food intake pattern was in accordance with the findings of the 2014 Individual Food Consumption Survey (SKMI) in Indonesia. ${ }^{40}$ Mohammad et al. reported that in mothers with energy intake reduced to $1,800 \mathrm{kcal}$, the high-fat diet group produced significantly higher milk fat content than the high-carbohydrate diet group. ${ }^{19}$ With a reduced energy intake that almost reached the minimum intake requirement, diets with high fat composition provided more fat milk substrate in the circulation, that would be more efficient for energy consumption use than that of de novo synthesis. The synthesis of endogenous fatty acids requires more energy, reaching $25 \%$ of energy from glucose. ${ }^{40}$

As much as $87-90 \%$ of breast milk consists of water. ${ }^{15}$ The water intake requirement of nursing mothers in our subjects' age range is $3.1 \mathrm{~L} /$ day. ${ }^{28}$ Most subjects consumed water exceeding the need. This excessive water consumption may be due to the belief that milk production will increase by drinking plenty of water. However, there is no data showing that increasing fluid intake will increase milk production, or vice versa. ${ }^{41}$

Fat content in milk varies greatly between individuals, as well as within an individual. ${ }^{42}$ In our study, the mean milk fat content of subjects was 59.4 (SD 15.9) $\mathrm{g} / \mathrm{L}$. In nursing mothers one month after delivery, Antonakou et al. found the fat content of the milk to be 31.73 (SD 16.42) g/L, ${ }^{13}$ while Mitoulas et al. found it to be 39.9 (SD 1.4) $\mathrm{g} / \mathrm{L} .8$
Differences in these results may be due to sampling techniques or measurement tools. Sampling was done only once, using a mid-feed sampling method, and directly checked using a creamatocrit. Although the 24-hour sampling of milk is ideal, Ruel et al. found that specimens taken at 6:00-8:00 in the morning approached the 24-hour average fat content of the milk. ${ }^{23}$

Villalpando et al. found a strong positive correlation between body fat mass and fat content of breast milk, ${ }^{20}$ in aggreement with research by Barbosa et al. ${ }^{21}$ Conversely, no significant correlation was found between fat content of milk and maternal body fat mass $(\mathrm{P}=0.743)$, total body fluid $(\mathrm{P}=0.442)$, or muscle mass $(\mathrm{P}=0.853)$. Similarly, Quinn et al. ${ }^{22}$ found that body composition, in this case the fat mass, was not a predictor of the fat content of milk. This result may be related to the possibility that adequate food intake was the main source of milk fat, so body composition had little effect.

Maternal dietary intake is the source of most milk fat. Wan et al. found high milk fat content [40.21 (SD 1.43) $\mathrm{g} / \mathrm{L}]$ in nursing mothers in North China, who experienced a shift in dietary patterns to high fat, high energy density, and low fiber. ${ }^{17}$ Milk fat content in our subjects was higher [59.4 (SD 15.9) g/L], but we found no correlations between breast milk fat content and intake of energy, fat, carbohydrates, protein, or water. Similarly, Antonakou et al. also found no correlation between the total fat content of breast milk and intake in nursing mothers one-month postpartum. ${ }^{13}$ Most nursing mothers in our study met the minimum requirements of intake, thereby providing sufficient substrate to produce milk fat. Subjects with fat intake of $<20 \%$ had higher carbohydrate intake. Breast milk fat in the subject can also be derived from de novo synthesis of carbohydrate substrates that are widely available.

A limitation of this study was that we inquired maternal fat intake by a single 24-hour food recall interview which may not reflect their usual daily intakeMothers had more difficultly remembering their fluid intake rather than food consumption, especially the volume of mineral water ingested. In addition, milk specimens were collected only once, and breastfeeding intervals and duration as well as milk volume were not examined, therefore, their associations with breast milk fat content could not 
Ardesy M. Kurniati et al: Associations of maternal body composition and nutritional intake with breastmilk fat content

be determined.

In conclusion, subjects in this study produce sufficient amount of breast milk fat. Further prospective study using food records or diaries and adjustment of confounding variables to determine the relationship of dietary intake with breast milk fat content may increase data accuracy, especially for water intake. Further research to obtain data of breast milk fatty acid composition is needed in Indonesia.

\section{Acknowledgments}

We would like to thank the research coordinator, Huzaimah, MD, OB-GYN and team for helpful comments and feedback on this study, as well as all RSIA Budi Kemuliaan midwifery staff for helping screen the subjects. We would also like to acknowledge the research assistants Miftahul Jannah, S.Gz, and Dika, S.Gz, as well as Arti Indira, MD, M. Gizi, for sharing and discussion about this research topic, Zalela, MD, for discussion about Nutrisurvey and Agung Nopriansah, MD, for comments that improved this manuscript.

\section{Conflict of interest}

None declared

\section{References}

1. Czank C, Mitoulas LR, Hartmann PE. Human milk composition-fat. In: Hartmann PE, editor. Hale \& Hartmann's textbook of human lactation. Amarillo: Hale Pub; 2007. p. 49-63.

2. Innis SM. Dietary triacylglycerol structure and its role in infant nutrition. Adv Nutr. 2011;2:275-83.

3. Isaacs J. Infant nutrition. In: Brown JE, editor. Nutrition through the life cycle. Brooks/Cole: Cengage Learning; 2010. p. 222-8.

4. Pusat data dan informasi kementerian kesehatan RI. Situasi dan analisis ASI eksklusif. Jakarta: Kementerian Kesehatan RI; 2014. p. 2-3

5. Murtaugh M, Lechtenberg E, Sharbaugh C, Sofka. Nutrition during lactation. In: Brown JE, editor. Nutrition through the life cycle. Brooks/Cole: Cengage Learning; 2010. 160-79.

6. Hachey DL, Thomas MR, Emken EA, Garza C, Brown-Booth L, Adlof RO, et al. Human lactation: maternal transfer of dietary triglycerides labeled with stable isotopes. J Lipid Res. 1987;28:1185-92.

7. Francois CA, Connor SL, Wander RC, Connor WE. Acute effects of dietary fatty acids on the fatty acids of human milk. Am J Clin Nutr. 1998;67:301-8.

8. Mitoulas LR, Kent JC, Cox DB, Owens RA, Sherriff JL, Hartmann PE. Variation in fat, lactose and protein in human milk over $24 \mathrm{~h}$ and throughout the first year of lactation. $\mathrm{Br}$ J Nutr. 2002;88:29-37.

9. Hausman Kedem M, Mandel D, Domani KA, Mimouni FB, Shay V, Marom R, et al. The effect of advanced maternal age upon human milk fat content. Breastfeed Med. 2013;8:116-9.

10. Lawrence RA. Breastfeeding: a guide for the medical profession. Maryland Heights: Mosby/Elsevier; 2011. p. 98-152.

11. Prentice A. The effect of maternal parity on lactational performance in a rural African community. In: Hamosh M, Goldman AS, editors. Human lactation 2. US: Springer; 1986. p. 165-73.

12. Osubor CC, Ibadin MO, Asonye CC. Lipid content of breast milk of lactating women in Benin City, Nigeria. Glob J Med Sci. 2004;3:23-7.

13. Antonakou A, Skenderi KP, Chiou A, Anastasiou CA, Bakoula C, Matalas AL. Breast milk fat concentration and fatty acid pattern during the first six months in exclusively breastfeeding Greek women. Eur J Nutr. 2013;52:963-73.

14. Neville MC, Picciano MF. Regulation of milk lipid secretion and composition. Annu Rev Nutr. 1997;17:159-83.

15. Perkumpulan Obstetri dan Ginekologi Indonesia. Konsensus nasional kebutuhan asupan air bagi ibu hamil, melahirkan dan menyusui. Jakarta: POGI; 2013. p. 5-12

16. Insull W, Hirsch J, James T, Ahrens EH. The fatty acids of human milk. II. Alterations produced by manipulation of caloric balance and exchange of dietary fats. J Clin Invest. 1959;38:443-50.

17. Wan ZX, Wang XL, Xu L, Geng Q, Zhang Y. Lipid content and fatty acids composition of mature human milk in rural North China. Br J Nutr. 2010;103:913-6.

18. Nasser R, Stephen AM, Goh YK, Clandinin MT. The effect of a controlled manipulation of maternal dietary fat intake on medium and long chain fatty acids in human breast milk in Saskatoon, Canada. Int Breastfeed J. 2010;5:3.

19. Mohammad MA, Sunehag AL, Haymond MW. Effect of dietary macronutrient composition under moderate hypocaloric intake on maternal adaptation during lactation. Am J Clin Nutr. 2009;89:1821-7.

20. Villalpando S, Prado MD. Interrelation among dietary energy 
Ardesy M. Kurniati et al: Associations of maternal body composition and nutritional intake with breastmilk fat content

and fat intakes, maternal body fatness, and milk total lipid in humans. J Mammary Gland Biol Neoplasia. 1999;4:28595.

21. Barbosa L, Butte NF, Villalpando S, Wong WW, Smith EO. Maternal energy balance and lactation performance of Mesoamerindians as a function of body mass index. Am J Clin Nutr. 1997;66:575-83.

22. Quinn EA, Largado F, Power M, Kuzawa CW. Predictors of breast milk macronutrient composition in Filipino mothers. Am J Hum Biol. 2012;24:533-40.

23. Ruel MT, Dewey KG, Martínez C, Flores R, Brown KH. Validation of single daytime samples of human milk to estimate the 24-h concentration of lipids in urban Guatemalan mothers. Am J Clin Nutr. 1997;65:439-44.

24. Miller EM, Aiello MO, Fujita M, Hinde K, Milligan L, Quinn EA. Field and laboratory methods in human milk research. Am J Hum Biol. 2013;25:1-11.

25. Kurniati AM, Sunardi D, SUngkar A. Kadar lemak ASI pada ibu menyusui usia reproduktif. Jurnal Konas XII Perinasia; 2016 Jan 16-20; Banjarmasin, South Borneo. Banjarmasin: Perinasia; 2016. p. 19-23.

26. Tumbelaka A, Riono P, Sastroasmoro S, Wirjodiarjo M, Pudjiastuti P, Firman K. Pemilihan uji hipotesis. In: Sastroasmoro S, Ismael S, editors. Dasar-dasar metodologi penelitian klinis. Jakarta: CV Sagung Seto; 2011. p. 32446.

27. Gallagher D, Heymsfield SB, Heo M, Jebb SA, Murgatroyd PR, Sakamoto Y. Healthy percentage body fat ranges: an approach for developing guidelines based on body mass index. Am J Clin Nutr. 2000;72:694-701.

28. Depkes RI. Tabel Angka kecukupan gizi yang dianjurkan bagi bangsa Indonesia. 2013 [cited 2014 Sep 30]. Available from: http://gizi.depkes.go.id/download/Kebijakan\%20Gizi/ Tabel\%20AKG.pdf

29. Geddes, DT. Gross anatomy of the lactating breast. In: Hartmann PE, editor. Hale \& Hartmann's textbook of human lactation. Amarillo: Hale Pub; 2007. p. 19-31.

30. Lawrence RA. Breastfeeding: a guide for the medical profession. Maryland Heights: Mosby/Elsevier; 2011. p. 40-61.

31. Amin W, Indrawan I, Sriwahyuni E. Pengaruh faktor sosial ibu terhadap keberhasilan menyusui pada dua bulan pertama. J Kedokt Brawijaya. 2014;28:146-50.

32. Ukegbu AU, Ebenebe EU, Ukegbu PO. Breastfeeding pattern, anthropometry and health status of infants attending child welfare clinics of a teaching hospital in Nigeria. S Afr J Clin Nutr. 2010;23:191-6.

33. Kristiansen AL, Lande B, Øverby NC, Andersen LF. Factors associated with exclusive breast-feeding and breast-feeding in Norway. Public Health Nutr. 2010;13:2087-96.

34. Al-Sahab B, Lanes A, Feldman M, Tamim H. Prevalence and predictors of 6-month exclusive breastfeeding among Canadian women: a national survey. BMC Pediatr. 2010;10:20.

35. Institute of Medicine. Weight gain during pregnancy: reexamining the guidelines. Washington, DC: The National Academies Press; 2009. p. 6.

36. Choua G, El Kari K, El Haloui N, Slater C, Aguenaou H, Mokhtar N. Quantitative assessment of breastfeeding practices and maternal body composition in Moroccan lactating women during six months after birth using stable isotopic dilution technique. Int J Matern Child Health. 2013;1:45-50.

37. Hopkinson JM. Nutrition in lactation. In: Hartmann PE, editor. Hale \& Hartmann's textbook of human lactation. Amarillo: Hale Pub; 2007. p. 371-83.

38. Sulistomo A, Sutarina N, Ilyas E. Hidrasi pada aktivitas khusus. In: Status hidrasi pada kondisi umum dan khusus. Jakarta: Badan Penerbit FK UI; 2014. p. 60-81.

39. Sherwood L. Human physiology: from cells to systems. 6th ed. Independence: Thomson/Brooks/Cole; 2007. p. 257-301.

40. Depkes RI. Studi diet total: survei makanan individu Indonesia. Jakarta: Balitbangkes; 2014. p. 37-70.

41. Uauy R, Dangour AD. Fat and fatty acid requirements and recommendations for infants of 0.2 years and children of 2-18 years. Ann Nutr Metab. 2009;55:76-96.

42. Lawrence RA. Breastfeeding: a guide for the medical profession. Maryland Heights: Mosby/Elsevier; 2011. p. 283-301.

43. Kent JC, Mitoulas LR, Cregan MD, Ramsay DT, Doherty DA, Hartmann PE. Volume and frequency of breastfeedings 